\title{
SELECTION AGAINST THE VARIEGATED GENOTYPE IN BARBAREA VULGARIS
}

\author{
R. A. E. TILNEY-BASSETT \\ Botany School, Oxford
}

Received 26.viii.63

\section{INTRODUCTION}

The variegated leaves of Barbarea vulgaris consist of a mixture of pure green areas and yellowish-white areas speckled with green flecks. The pure green areas may be whole leaves, sectorial leaves green on one side of the midrib and variegated on the other, or isolated sectors of the leaf blade. In mature plants the leaves frequently have a characteristic pattern somewhat like a periclinal chimera with a yellowish-white, speckled margin and a green centre.

The breeding experiments of Dahlgren (1921) and Andersson (1924) showed that variegation was caused by a recessive gene or genes, but beyond this their results were inconclusive.

\section{BREEDING AND DEVELOPMENT}

Reciprocal crosses between true-breeding green and variegated stock plants gave 371 green offspring, and a selection of these, when selfed, segregated into green and variegated seedlings. The $\mathrm{F}_{3}$ generation contained one class of variegated families, true-breeding, and two classes of green families, one consisting of 11 pure green and the other of 18 segregating green families, which is in good agreement with the proportion expected from a $3: 1 F_{2}$ segregation of one homozygous green : 2 heterozygous green $F_{2}$ families. The $F_{2}$ and $F_{3}$ segregations both showed a significant deviation from the monohybrid $3:$ I ratio owing to a deficit of variegated seedlings (table 1 ). The slight heterogeneity between individual $F_{2}$ and $F_{3}$ families though statistically significant, is of no great moment.

Seeds germinated in J.I. Seed Compost at $20^{\circ} \mathrm{C}$. and a $\mathrm{I} 5$-hr. day gave the following results for all the $\mathrm{F}_{3}$ families; each contained 200 or 4 oo seeds : (I) Ten true-breeding variegated families produced 25.98 seedlings. Mean germination 68.37 per cent.; range $49 \cdot 00-88 \cdot 50$ per cent. (2) Eleven true-breeding green families produced 3446 seedlings. Mean germination $82 \cdot 05$ per cent; range $72 \cdot 50-90 \cdot 25$ per cent. (3) Eighteen segregating families produced 4854 seedlings. Mean germination $71 \cdot 38$ per cent.; range $57 \cdot 50-86 \cdot 00$ per cent.

These results show that seed is less viable from the average variegated family than from a green family. Consequently, the less viable variegated seeds depress the germination of the segregating families. This is confirmed by the mean germination of the segregating families which lies between the values for the true-breeding families. The poorer germination of variegated seeds explains the deviation from the $3: 1$ segregation. Furthermore, the segregating $F_{3}$ families produced not more, but somewhat fewer green seedlings than expected from a $3: 1$ ratio and 82 o5 per cent germination. Hence there can have been no selective elimination of variegated seed before harvesting, but only during germination. 
TABLE I

Total offspring from segregating families of the $F_{2}$ and $F_{3}$ generations showing a significant deviation from the $3: I$ ratio owing to a deficit of variegateds

\begin{tabular}{|c|c|c|c|c|c|c|c|}
\hline \multicolumn{4}{|c|}{ Nos. families and offspring } & \multicolumn{4}{|c|}{ Significance tests } \\
\hline Families & G & $\mathrm{V}$ & $\mathrm{T}$ & & $\chi^{2}$ & d.f. & $\mathbf{P}$ \\
\hline \multicolumn{8}{|c|}{$F_{2}$ generation } \\
\hline 9 & 3206 & 763 & 3969 & $\begin{array}{l}\text { Total } \chi^{2} \\
\text { Deviation } \chi^{8} \\
\text { Heterogeneity } \chi^{2}\end{array}$ & $\begin{array}{l}84 \cdot 2 \\
70 \cdot 6 \\
13 \cdot 6\end{array}$ & $\begin{array}{l}9 \\
1 \\
8\end{array}$ & $\begin{array}{c}\text { v. small } \\
0 \cdot 10\end{array}$ \\
\hline \multicolumn{8}{|c|}{$F_{s}$ generation } \\
\hline 18 & $396 \mathrm{I}$ & 893 & 4854 & $\begin{array}{l}\text { Total } \chi^{2} \\
\text { Deviation } \chi^{2} \\
\text { Heterogeneity } \chi^{2}\end{array}$ & $\begin{array}{r}144 \cdot 8 \\
112 \cdot 8 \\
32 \cdot 0\end{array}$ & $\begin{array}{r}18 \\
1 \\
17\end{array}$ & $\begin{array}{l}\text { v. small } \\
0.015\end{array}$ \\
\hline \multicolumn{5}{|c|}{$F_{2}+F_{3}$ combined heterogeneity $\chi^{8}$} & $45 \cdot 6$ & 25 & 0.007 \\
\hline
\end{tabular}

Individual seedlings differ in the stage of growth at which variegation first appears (table 2). Thereafter, it does not necessarily develop in each leaf but, generally speaking, the later the initiation of variegation the lower its frequency during subsequent development. Mature plants therefore

TABLE 2

Relationship between the stage of leaf development and the first appearance of variegation in 373 seedlings from six segregating families of the $F_{3}$ generation

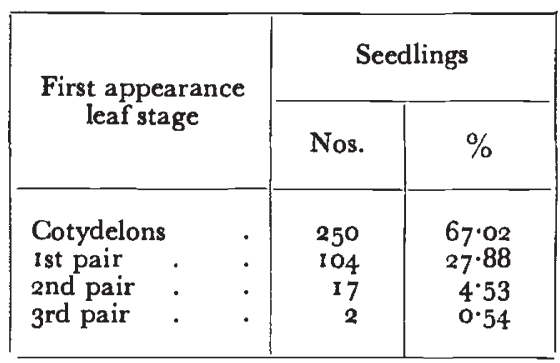

show a wide variation in the phenotypic expression of variegation, which is presumably controlled by modifying genes.

The growth of green and variegated plants was compared by measuring their fresh weights under different light conditions (table 3). The fresh weight of young green plants was always greater than the variegated especially at the lowest light level. This result agrees with the growth in the garden where the green is always more vigorous than the variegated. 
TABLE 3

Comparison of the fresh weights of green and variegated plants grown for 122 days at $18^{\circ} \mathrm{C}$. under varying light intensities, five plants at each level

\begin{tabular}{|c|c|c|c|}
\hline \multirow{2}{*}{\multicolumn{2}{|c|}{ Light level }} & \multicolumn{2}{|c|}{ Mean fresh weight per plant } \\
\hline & & G & V \\
\hline $\begin{array}{l}\text { High } \\
\text { Medium } \\
\text { Low }\end{array}$ & $\dot{.}$ & $\begin{array}{l}18.5 \text { gms. } \\
5.5 \text { gms. } \\
2.5 \text { gms. }\end{array}$ & $\begin{array}{l}18.0 \text { gms. } \\
4.5 \text { gms. } \\
\text { I.7 gms. }\end{array}$ \\
\hline
\end{tabular}

\section{SELECTION AGAINST VARIEGATED PLANTS}

The breeding results show that variegation is controlled by the action of a recessive gene. But owing to the reduced viability of seeds with the homozygous recessive genotype, there is a marked deviation from the expected $3: \mathrm{I}$ ratio. The reduced viability of the variegated seeds is followed by the poorer growth of the variegated seedlings. Hence there is a selection pressure against the variegated genotype throughout development from the immature seed to the mature plant, a selection pressure which would be quite sufficient to reduce the variegated plants in the wild to a very low frequency maintained by the pressure of mutation.

Acknowledgments.-I would like to thank Professor C. D. Darlington for his invaluable supervision, and the Christopher Welch Trustees for a Scholarship which enabled me to prepare this account while studying for a D.Phil. degree in the University of Oxford.

\section{REFERENCES}

ANDERsSON, I. 1924. Structural mosaics and inheritance of variegation in Barbarea vulgaris. F. Genet, 14, 185-195.

DAHLGREN, K. V. O. I921. Vererbungsversuche mit einer buntblättrigen Barbarea vulgaris. Hereditas, Lund, 2, 88-98. 